\title{
Physical Properties and Compressive Strength of the Technical Plaster and Local Juss
}

\author{
Zeki A. Aljubouri \\ Department of Geology \\ College of Science \\ Mosul University
}

(Received 13/11/2008, Accepted 19/3/2009)

\begin{abstract}
Five physical properties (water/powder ratio, setting time, fineness, porosity and dendsity) and compressive strength were determined and compared for technical plaster and local juss.Data were monitored using a standard dental stone. The relationships between these properties were also studied. It was revealed that local juss has inferior properties compared with technical plaster. It has lower compressive strength; higher water/powder ratio; shorter setting time; larger grain size and higher porosity. There is an inverse relationship between compressive strength and the two properties water/powder ratio and porosity. There is a direct relationship between compressive strength and the two properties particle size and density. There is also a direct relationship between setting time and the two properties particle size and water/powder ratio.
\end{abstract}

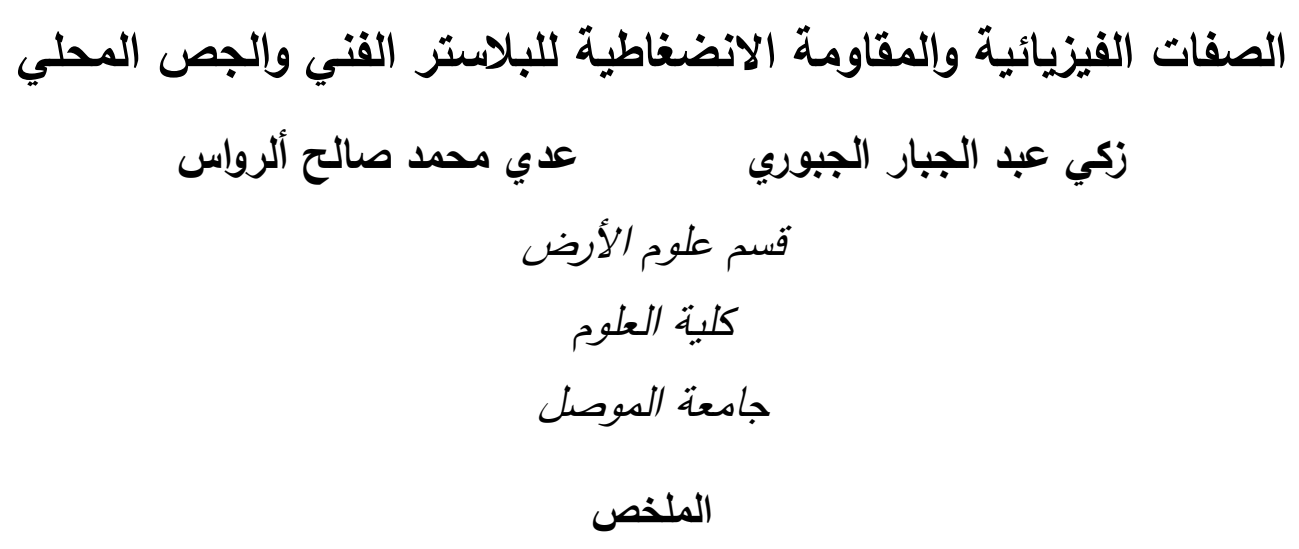

تم دراسة خمس خواص فيزيائية وهى (نسبة الماء إلى المسحوق وزمن التجمد والنعومة والمسامية والكثافة) والمقاومة الانضغاطية لكل من البلاستر الفني والجص المحلي وتم استعمال حجر الأسنان كنموذج

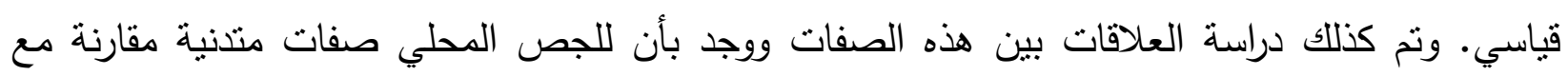

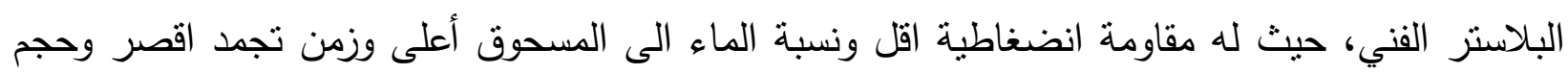

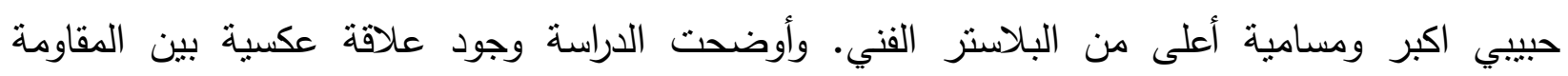
الانضغاطية والصفتين نسبة الماء الى المسحوق والمسامية. وعلاقة طردية بين المقاومة الانضغاطية

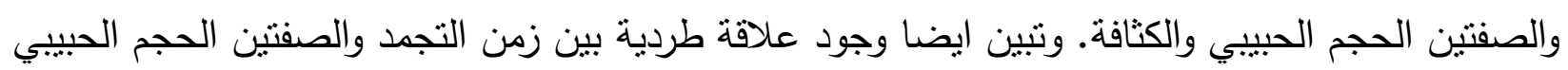
ونسبة الماء الى المسحوق. 


\section{INTRODUCTION}

Ten samples of local plastering juss were collected from two juss stores ( 5 samples each) representing two production plants (two koors) from the main juss production area in Nineveh Governorate, situated at a distance of about $(12 \mathrm{~km})$ northwest of Mosul, near "Sahaji" village. Another (20) samples of "Ahlia" and Malej technical plasters were chosen from six bags (three bags each) purchased from the local market, each bag weighing around $(30 \mathrm{Kg}$ ) by quartering method. Five representative samples of an English dental stone, type "Kaffir" taken from two kilograms of the stone, purchased from a medical supply bureau in Mosul, were used as reference standard in this study. All data in the tables to follow represent averages of either ten (local juss and technical plaster) or five (dental stone) analyses.

The purpose of this work is to study five physical properties (water/powder ratio, setting time, fineness, porosity and density) and compressive strength for local juss and technical plaster; to make a comparison of these properties between the two types of gypsum products and to find the relationships between these properties.

\section{Gypsum products}

\section{DEFINITIONS}

Materials that resulted from the calcinations of gypsum $\left(\mathrm{CaSO}_{4} \cdot 2 \mathrm{H}_{2} \mathrm{O}\right)$ and having the chemical composition of hemihydrate $\left(\mathrm{CaSO}_{4} \cdot 1 / 2 \mathrm{H}_{2} \mathrm{O}\right)$. Although identical in composition and x-ray diffraction peaks, they are different in their physiomechanical properties. They include three main types: local juss, plaster and dental stones and each type has several varieties.

\section{Local juss}

The word "juss" is derived from the Assyrian word "jasso". Local juss in Nineveh Governorate is a material produced from calcined gypsum by the "Koor method". Gypsum rock pieces are placed on openings in the koor dome and the heat source is at the base of the dome. Heating continues for 24 hours. The final product the juss is a mechanical mixture of anhydrite, bassanite and unburnt gypsum.

\section{Technical plaster}

Is calcined gypsum produced by heating gypsum in either vertical or horizontal furnaces at temperature between $\left(120\right.$ to $\left.170{ }^{\circ} \mathrm{C}\right)$ and for a period of half to three hours. It mainly consists of bassanite of $\beta$-type. Synonyms are: technical juss, technical gyps or gyps only.

\section{Dental stone}

Is a high quality plaster of Paris, produced by heating gypsum under high pressure. It consists largely of bassanite of the type $\alpha$-hemihydrate. It has superior compressive strength and physical properties in comparison with ordinary plaster.

\section{METHODOLOGY}

Compressive strength determinations were carried out at the College of Engineering laboratories, University of Mosul, using an ELE digital compression machine, type (1435- 3-039).

Test samples consist of hydrated plaster ( gypsum ) cubes measuring $(5 \times 5 \times 5 \mathrm{~cm})$ and prepared in stainless steel mold with three cube cavities. 
Water/powder ratios (W/P), and setting time, were determined using "Vicat" apparatus" and after preparing the proper consistency according to (ADA,1975) specification. Particle size analyses were carried out using seives of the sizes $(250,150,90$, and 45) microns and according to (Friedman and Johnson, 1982). Porosity measurements were carried out on the same cubes of the hydrated plaster used for compressive strength tests. Loss in weight of the hydrated cube, usually after seven days or until a constant weight is reached, is equal to the porosity of gypsum product. (AlRawas, 2002). Density determinations were carried using the pycnometer (Density bottle) method. (Hurlbut and Klein, 1977). All these analyses were carried out at the Department of Geology,University of Mosul. For further details of the methods see (Al-Rawas, 2002).

\section{RESULTS AND DISUSSION}

The five physical properties and compressive strength vary in quality from dental stone, having superior, to technical plaster with medium quality, ending with local juss with poor or low properties. To avoid repetition of references, these are only stated throughout the discussion regarding the relationships between these properties.

\section{a- Compressive strength}

Table (1) shows that dental stone has the highest compressive strength (30 Mpa) due to the high degree of cohesion of its particles followed by technical plaster (about 20 Mpa) and the local juss, which has very low (7 Mpa) compressive strength.

\section{b- Water/powder ratio (W/P)}

This is defined as the amount of water (in milliliter) added to (100 g) gypsum product to produce a standard consistency. This consistency is defined as one which will allow the cone of Vicat apparatus to penetrate through a distance of $(30 \mathrm{~mm})$.

Table (1) shows that dental stone has the least (W/P) of about (30) followed by technical plaster (45 to 50) and then local juss (about 55).

The theoretical amount of water that should be added to $(100 \mathrm{~g})$ of gypsum product (plaster) to completely convert it to gypsum is $(18.63 \mathrm{~g})$. However, this would give rather hard unworkable consistency, and hence additional water must be added which is "pore-water" to give good consistency manipulation (Al-Rawas, 2002).

\section{c- Setting time}

This is the time (in minutes) required for the standard consistency to give the needle of Vicat apparatus zero penetration.

Dental stone has relatively long setting times (8-12 min.) compared with technical plaster (6-8 min.) and local juss (about 5 min.) (Table 1).

Setting time must be long enough to allow the craftsman (a dentist, for example) to manipulate gypsum product into the desired shape. However, there are several retarders like borax (di-sodium tetraborate) and accelerators, like potassium sulphate for lengthening or shortening setting time respectively and as desired.(Craig, 1997).

\section{d- Fineness}

This is the particle size of gypsum product and is measured in micron $\left(1 \mu=10^{-6}\right.$ $\mathrm{mm})$. Gypsum products must have specified particle size $(-250$ to +45 micron) conforming with the range of international standards given by (ADA, 1975). For dental stone and technical plaster, powders must all pass through (250 micron) and at least $90 \%$ is between $(-150$ and $+190 \mu)$. The rest is below (90 microns). There is no 
standar dparticle size for local juss, however in the present study, about $(30 \%)$ of the powder retained the (250 micron) and the rest between (250) and (90) micron (Table 1).

\section{e- Porosity}

The porosity depends on the degree of cohesion or compaction of powder. The higher the compaction the lower the porosity. Dental stone has the least porosity of about $(20 \%)$ followed by technical plaster (38\%) and local juss (42\%) (Table 1).

\section{f- Density}

In general, gypsum products consist almost entirely of the mineral bassanite $\left(\mathrm{CaSO}_{4} \cdot 1 / 2 \mathrm{H}_{2} \mathrm{O}\right)$ (Al-Rawas, 2002; Aljubouri and Al-Rawas, 2006). Theoretical density of bassanite is 2.73 (JCPDS, 1974).

In accordance with previous physical properties, which depend on cohesion or compaction of the gypsum product, the dental stone should have the highest density, followed by the technical plaster and the local juss. However, there is an exception to this rule. Local juss has the highest $\left(2.7 \mathrm{~g} / \mathrm{cm}^{3}\right)$ density, followed by dental stone $(2.5)$ and by technical plaster (2.4) (Table 1). This is due to the fact that local juss is a mechanical mixture of the three calcium sulphate phases, where the anhydrite being the dominant phase $(70 \%)$ followed by the hemihydrate or bassanite $(20 \%)$ and unburnt gypsum (10\%) (Al-Rawas, 2002; Aljubouri and Al-Rawas, 2006).

Table 1: Compressive strength and physical properties of gypsum products of the present study.

\begin{tabular}{|l|c|c|c|}
\hline \multirow{2}{*}{ Property } & \multicolumn{3}{|c|}{ Gypsum Product } \\
\cline { 2 - 4 } & Dental Stone & Technical Plaster & Local Juss \\
\hline Compressive strength (Mpa) & 30 & 20 & 7 \\
\hline Water/Powder ratio (W/P) & 30 & $45-50$ & $50-55$ \\
\hline Setting time (min.) & $8-12$ & $6-8$ & 5 \\
\hline \multirow{2}{*}{ Particle size $(\mu)$} & $-250,100 \%$ & $-250,100 \%$ & $+250,30 \%$ \\
& $+90,90 \%$ & $+90,90 \%$ & $-250+90,70 \%$ \\
\hline Porosity $(\%)$ & 20 & 38 & 42 \\
\hline Density $\left(\mathrm{g} / \mathrm{cm}^{3}\right)$ & 2.5 & 2.4 & 2.7 \\
\hline
\end{tabular}

\section{Relationships between Compressive Strength and Physical Properties}

The purpose of studying the relationships between the compressive strength and physical properties is to help in the improvement of the quality of gypsum product by altering some of these properties. For example, from studying the relation between compressive strength (C.S.) and water/powder ratio (W/P), it is advisable that the first property should be increased and the second should be decreased by proper treatments. There are some propertis not important and were not studied by previous workers and thus would not be discussed here. For example (C.S versus setting time; setting time versus density; setting time versus porosity).

\section{A- Compressive strength versus water/powder ratio}

There is an inverse relationship between compressive strength and water/powder ratio, where one increases at the expense of the other. The reason is as the (W/P) increases, the pore water increases too which helps the gliding of particles and coherence is decreased and hence compressive strength decreases too. All researchers and text book 
authors confirm this inverse relationship, among them (Anderson, 1961, p.184; Skinner and Phillips, 1962, p.39; O'brien and Ryge, 1978, p.67; Craig, 1997, p.47; Noort, 2002, p.208; Abdulla, 2006, p.10). Table (2) and (Fig.1) show this relationship.

Table 2: Relationship between compressive strength and water/powder ratio (W/P). Ahlia, Malej , technical plasters and local juss.

\begin{tabular}{|ccc|c|}
\hline Malej & $\begin{array}{c}\text { Compressive Strength (C.S.) Mpa } \\
\text { Ahlia }\end{array}$ & Local Juss & Water/Powder Ratio (W/P) \\
\hline 21.0 & 20.0 & --- & 50 \\
\hline 18.2 & 17.3 & 7.3 & 55 \\
\hline 15.2 & 14.6 & 5.2 & 60 \\
\hline 13.1 & 12.7 & 4.5 & 65 \\
\hline--- & --- & 4.2 & 70 \\
\hline
\end{tabular}

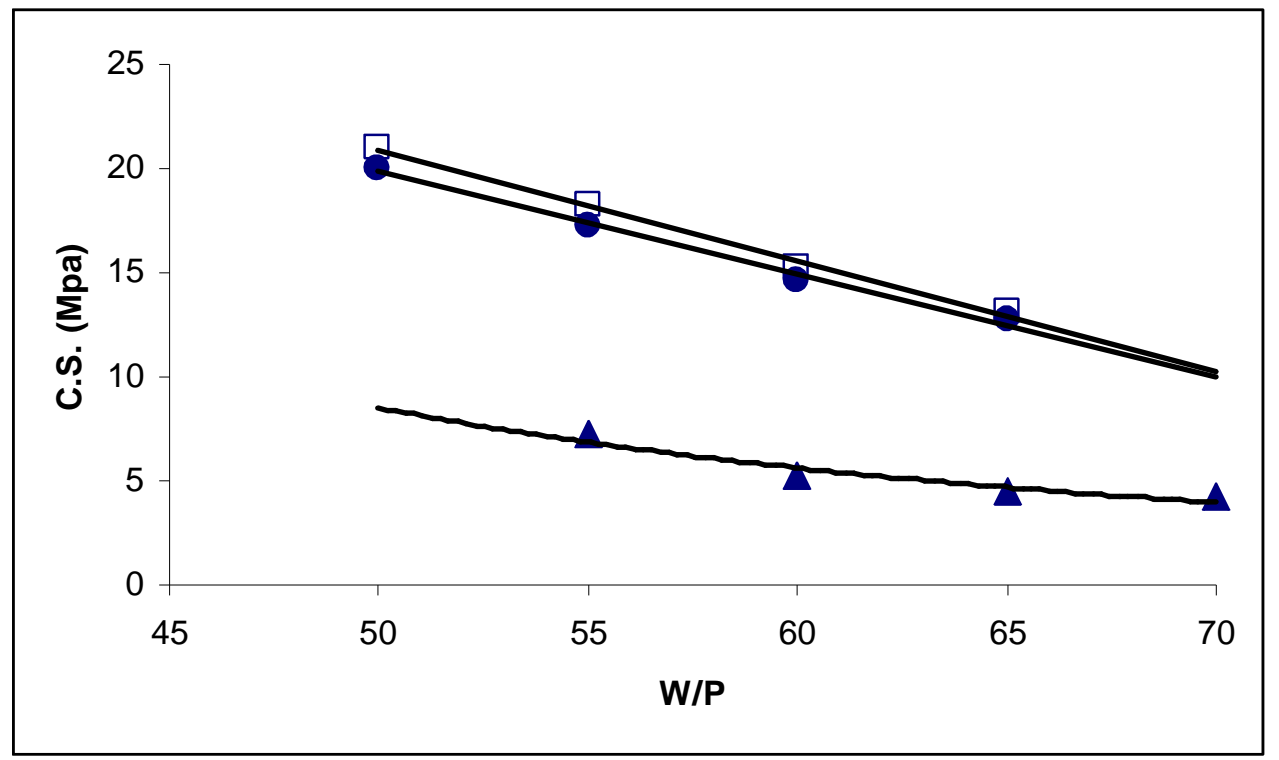

Fig.1: Relationship between compressive strength (C.S) and water/powder (W/P) ratio. Ahlia (solid circles), Malej (open squares) technical plasters and local juss (solid triangles).

\section{B- Compressive strength versus particle size}

The larger the particle size of gypsum product, the higher its compressive strength. The reason is that at large particle size the total surface area decreases which leads to lesser amount of pore water and therefore higher compressive strength (Craig et al., 2004, p.203). Table (3) and ( Fig. 2) show this relationship. 
Table 3: Relationship between compressive strength and particle size. Ahlia and Malej technical plaster.

\begin{tabular}{|c|c|c|}
\hline \multicolumn{2}{|c|}{ Compressive Strength (C.S.) (Mpa) } & \multirow[t]{2}{*}{ Particle Size $(\mu)$} \\
\hline Ahlia & Malej & \\
\hline 18.3 & 18.5 & +45 \\
\hline 19.4 & 19.9 & +90 \\
\hline 20.6 & 21.4 & +150 \\
\hline
\end{tabular}

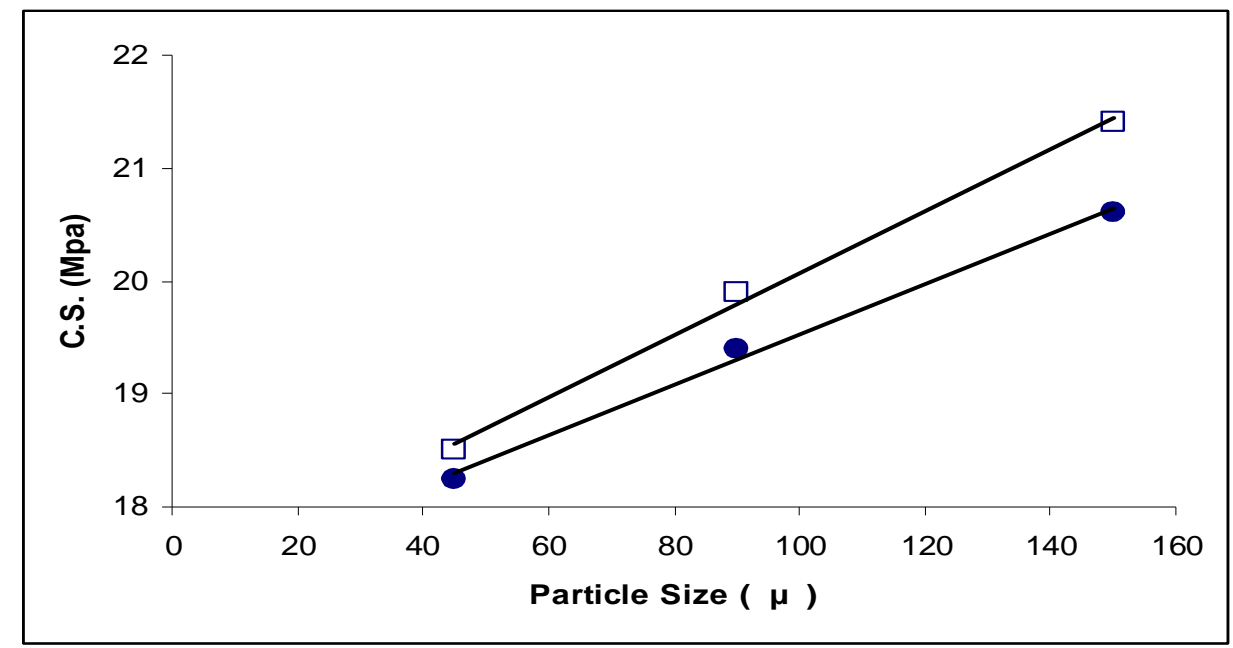

Fig. 2: Relationship between compressive strength (C.S.) and particle size ( $\mu$ ). Ahlia (solid circles) and Malej (open squares) technical plasters.

\section{C- Compressive strength versus porosity}

There is an inverse relationship between compressive strength and porosity. The higher the porosity, the less the compressive strength. High porosity leads to more pore water, more sliding of particles and less cohesion which results in lower compressive strength (Skinner and Phillips, 1962, p.43; O'brien and Ryge, 1978, p.65; McCabe, 1985, p.31). Table (4) and ( Fig.3) show this relationship.

Table 4: Relationship between compressive strength and porosity. Ahlia and Malej technical plasters.

\begin{tabular}{|cc|cc|}
\hline \multirow{2}{*}{$\begin{array}{c}\text { Compressive Strength (C.S.) (Mpa) } \\
\text { Ahlia }\end{array}$} & \multicolumn{3}{|c|}{ Porosity \% } \\
Malej & Ahlia & Malej \\
\hline 18.3 & 18.5 & 38.3 & 37.6 \\
\hline 19.4 & 19.9 & 35.7 & 35.2 \\
\hline 20.6 & 21.4 & 32.8 & 32.3 \\
\hline
\end{tabular}




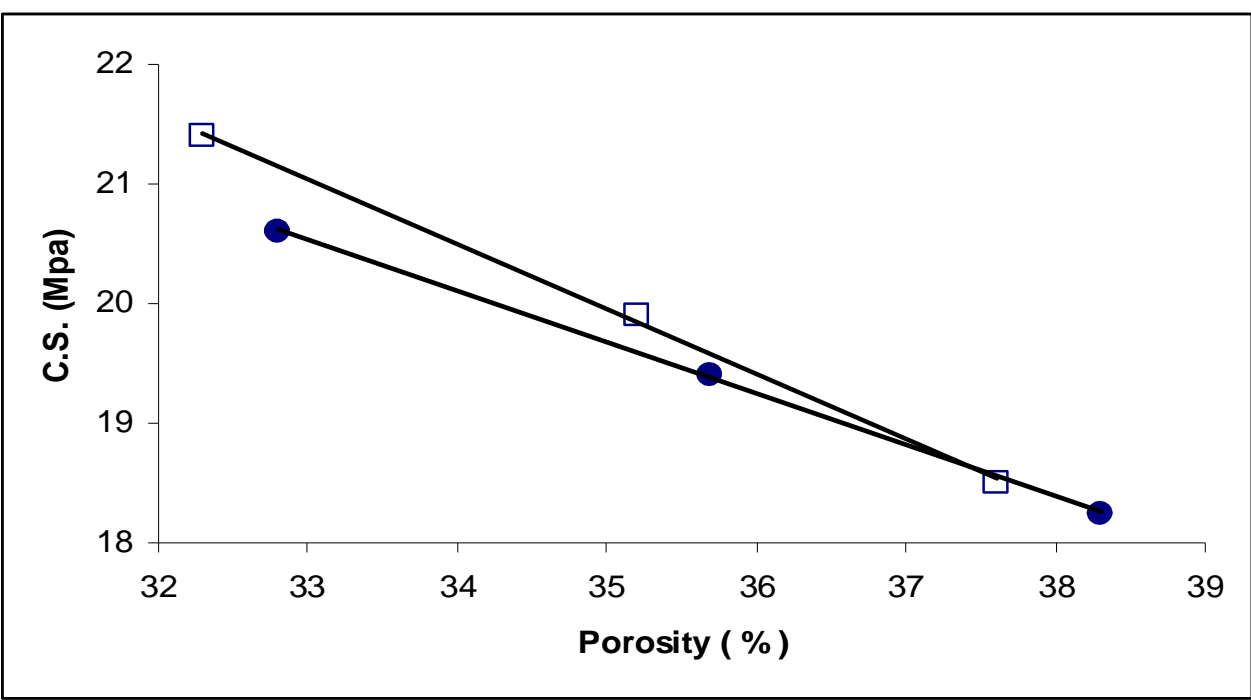

Fig.3: Relationship between compressive strength (C.S.) and porosity (\%). Ahlia (solid circles) and Malej (open squares) technical plasters.

\section{D- Compressive strength versus density}

When gypsum product consists almost exclusively of one phase, which is bassanite $\left(\mathrm{CaSO}_{4} \cdot 1 / 2 \mathrm{H}_{2} \mathrm{O}\right)$, then the higher the density, the higher the compressive strength. High density means more cohesiveness which gives higher compressive strength ( $\mathrm{O}^{\prime}$ brien and Ryge, 1978, p.62; Combe, 1986, p.303). In the present study, this relationship is well illustrated in the case of dental stone $\left(D=2.50 \mathrm{~g} / \mathrm{cm}^{3}, C . S .=30 \mathrm{Mpa}\right)$ and technical plaster $\left(\mathrm{D}=2.40 \mathrm{~g} / \mathrm{cm}^{3}, \mathrm{C} . \mathrm{S} .=20 \mathrm{Mpa}\right)$ (Table 1$)$.

However, the relationship does not hold for local juss, having a density of $(2.70$ $\mathrm{g} / \mathrm{cm}^{3}$ ) and compressive strength of only ( $7 \mathrm{Mpa}$, Table 1). This is because local juss consists of three phases (anhydrite $70 \%$, bassanite $20 \%$ and gypsum $10 \%$ ) and when the determined density of each phase (taking the lower limit of the density of anhydrite, 2.89 $\mathrm{g} / \mathrm{cm}^{3}$, Hurlbut and Klein, 1977, p.300) is multiplied by the proportion of each phase and then added up, the total density is $\left(2.73 \mathrm{~g} / \mathrm{cm}^{3}\right)$ which is very near to the determined density for local juss in Table (1). Anhydrite and gypsum powders in the juss, unlike bassanite or plaster, do not have the ability of setting, i.e. to solidify into a hard mass and hence juss has low compressive strength due to its low content of basanite ( $20 \%$ only).

\section{E- Setting time versus particle size}

There is a direct relationship between setting time and particle size. The larger the particle size, the longer the setting time. Larger particle size gives smaller surface area which means a smaller area is exposed to dissolution. Also there are smaller number of gypsum "nuclei" leading to longer setting time (Skinner and Phillips, 1962, p.39, AlQuaraghooli,1989). Table (5) and (Fig.4) show this relationship. 
Table 5: Relationship between setting time and particle size. Ahlia and Malej technical plasters.

\begin{tabular}{|cc|c|}
\hline \multicolumn{2}{|c|}{ Setting Time (min.) } \\
Ahlia & Malej & Particle Size $(\boldsymbol{\mu})$ \\
\hline 7 & 8 & +45 \\
\hline 8 & 9 & +90 \\
\hline 10 & 11 & +150 \\
\hline
\end{tabular}

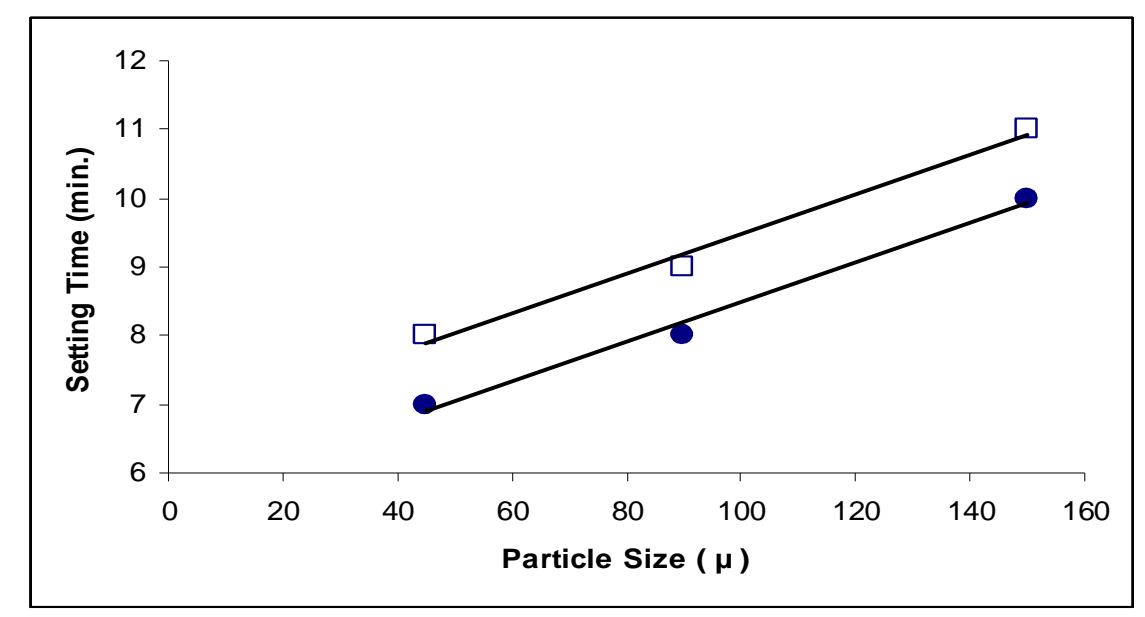

Fig.4: Relationship between setting time and particle size. Ahlia (solid circles) and Malej (open squares) technical plasters

\section{F- Setting time versus water/powder ratio (W/P)}

The higher the $(\mathrm{W} / \mathrm{P})$, the longer the setting time. At higher $(\mathrm{W} / \mathrm{P})$ the number of gypsum nulei for crystallization would decrease relative to the larger volume of available water and leading to longer setting time (O'brien and Ryge, 1978, p.66; McCabe, 1985, p.31). Table (6) and (Fig.5) explain this relationship.

Table 6: Relationship between setting time and water/powder ratio. Ahlia and Malej technical plasters.

\begin{tabular}{|c|c|c|}
\hline \multicolumn{2}{|c|}{ Setting Time (min.) } & \multirow{2}{*}{ Water/Powder Ratio (W/P) } \\
\hline Ahlia & Malej & \\
\hline 7 & 8 & 50 \\
\hline 9 & 10 & 55 \\
\hline 10 & 11 & 60 \\
\hline 12 & 13 & 65 \\
\hline
\end{tabular}




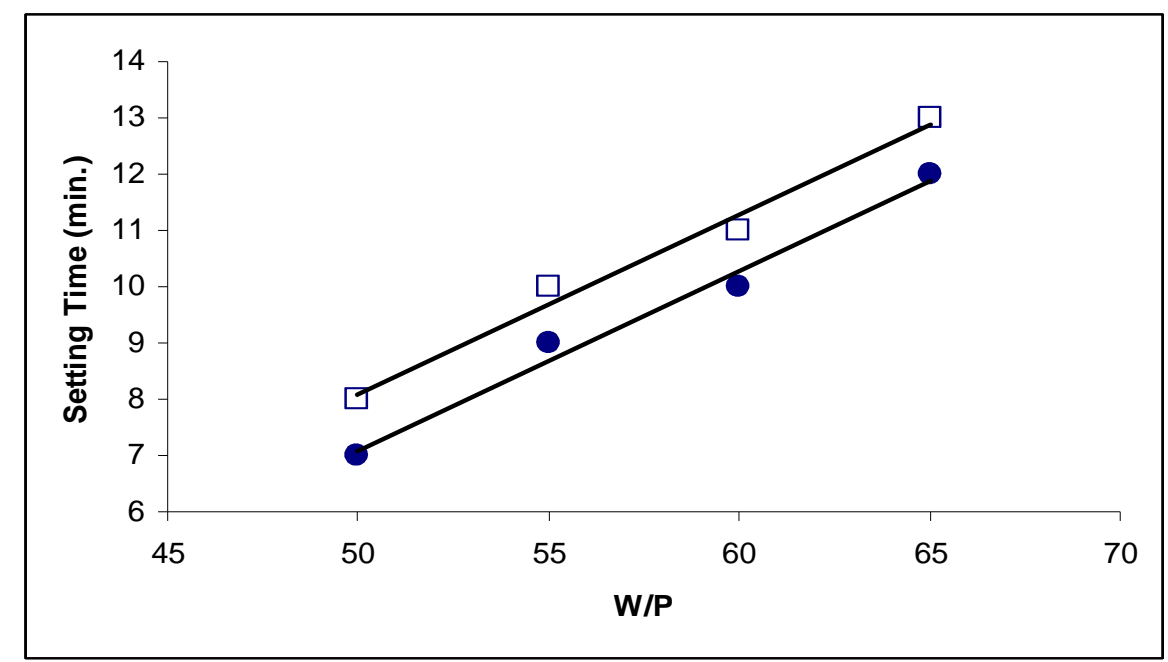

Fig.5: Relationship between setting time and water/powder ratio (W/P). Ahlia (solid circles) and Malej (open squares) technical plasters.

\section{CONCLUSIONS}

The present study concludes at:

1. Local juss has inferior properties (lower compressive strength, higher water/powder ratio, shorter setting time, larger grain size and higher porositry) compared to the technical plaster. The higher density of local juss $\left(2.70 \mathrm{~g} / \mathrm{cm}^{3}\right)$ than technical plaster $\left(2.40 \mathrm{~g} / \mathrm{cm}^{3}\right)$ is due to the fact that it consists of a mixture of anhydrite $(70 \%)$, bassanite $(20 \%)$ and gypsum $(10 \%)$.

2. There is an inverse relationship between compressive strength and the two properties water/powder ratio and porosity. On the other hand, there is a direct relationship between compressive strength and the two properties particle size and density

3. There is a direct relationship between setting time and the two properties particle size and water/powder ratio.

\section{REFERENCES}

Abdulla, M.A., 2006. Evaluation of Some Properties of Gysum Products and Acrylic Resin by the Use of Some Additives and Microwave Technique Unpublished M.Sc. Thesis. College of Dentistry, University of Mosul, $169 \mathrm{p}$.

Aljubouri, Z.A.J. and Al-Rawas, A.M.S., 2006. The Petrography and Mineralogy of Technical Plaster and Local Juss. Iraqi Jour. Earth Sci., Vol.6, No.1, pp.1-11.

Al-quaraghooli, 1989. Mineral and Chemical Properties of Iraqi Gypsum. Units and Methods of Production and their Effects on the Quality of Juss and Bourak Products. Jour. Geol. Soc. Iraq. Vol. 22, No. 2, pp. 154-172. (In Arabic)

Al-Rawas, A.M.S., 2002. Study of the Chemical, Mineralogical and Physiomechanical Properties of Technical Plaster and Local Juss. Unpub. M.Sc. Thesis, College of Science, Univ. of Mosul, 83 p.

American Dental Association Specification (ADA), 1975. Guide to Dental Materials and Devices. $7^{\text {th }}$ edition, Chicago, ADA, 354p.

Anderson, J.N., 1961. Applied Dental Materials. Blackwell, Oxford, 356 p. 
Combe, E.C., 1986. Notes on Dental Materials. $5^{\text {th }}$ Edition, Huntsman, London, 253 p.

Craig, R.G., 1997. Restorative Dental Materials. Mosby Inc., St. Lewis Missouri, USA, $540 \mathrm{p}$.

Craig, R.G., Powers, J.M. and Wataha, J.C., 2004. Dental Materials. $8^{\text {th }}$ Edition, Mosby Inc., St. Lewis, Missouri, USA, 340p.

Friedman, G.M. and Johnson, K.G..1982. Exercises in Sedimentology. Wiley and Sons Inc. New York. USA. Exer 2 and 4. pp 81-89.

Hurlbut, C.S. and Klein, C., 1977. Manual of Mineralogy (after James Dana), Wiley and Sons, New York, USA, 532 p.

Joint Committee on Powder Diffraction Standards (JCPDS), 1974. Card No. 24-1068, Calcium Sulfate Hydrate. New York, USA.

Lapedes, D.N., 1978. McGraw-Hill Dictionary of Scientific and Technical Terms. McGraw-Hill Book Company, New York, USA, 1771 p.

McCabe, J.F., 1985. Anderson's Applied Dental Materials. $6^{\text {th }}$ Edition, Blackwell, London, UK, $178 \mathrm{p}$.

Noort, V.R., 2002. Introduction to Dental Materials. $2^{\text {nd }}$ Edition. Mosby Inc., Sr. Lewis, Missouri, USA, $298 \mathrm{p}$.

O'brien, W.J. and Ryge, G., 1978. An Outline of Dental Materials. W.B. Saunders Co., Philadelphia, USA, 442p.

Skinner, E.W. and Phillips, R.W., 1962. The Science of Dental Materials. W.B. Saunders Co., Philadelphia, USA, 636 p. 